\title{
Danish Experiences in Biomass Corrosion and Recent Areas of Research
}

\author{
Montgomery, Melanie; Malede, Yohanes Chekol; Wu, Duoli; Dahl, Kristian Vinter
}

Published in:

Corrosion

Link to article, DOI:

$10.5006 / 2963$

Publication date:

2019

Document Version

Peer reviewed version

Link back to DTU Orbit

Citation (APA):

Montgomery, M., Malede, Y. C., Wu, D., \& Dahl, K. V. (2019). Danish Experiences in Biomass Corrosion and Recent Areas of Research. Corrosion, 75(4), 358-366. https://doi.org/10.5006/2963

\section{General rights}

Copyright and moral rights for the publications made accessible in the public portal are retained by the authors and/or other copyright owners and it is a condition of accessing publications that users recognise and abide by the legal requirements associated with these rights.

- Users may download and print one copy of any publication from the public portal for the purpose of private study or research.

- You may not further distribute the material or use it for any profit-making activity or commercial gain

- You may freely distribute the URL identifying the publication in the public portal

If you believe that this document breaches copyright please contact us providing details, and we will remove access to the work immediately and investigate your claim. 


\title{
Danish Experiences in Biomass Corrosion and Recent Areas of Research
}

\author{
Melanie Montgomery*§, Yohanes Chekol Malede*, Duoli Wu** Kristian Vinter Dahl* \\ *DTU-Mechanical Engineering, Building 425, Produktionstorvet, 2800 Lyngby, Denmark. \\ **College of Mechanical Engineering, Yangzhou University, Yangzhou 225127, China. (formerly DTU- \\ Mechanical Engineering) \\ ${ }^{\S}$ Corresponding authorEmail:mmon@mek.dtu.dk
}

\begin{abstract}
In Denmark, biomass has been implemented in the majority of power plants either by firing biomass alone or co-firing of biomass and fossil fuels/additives. This has resulted in an accumulation of experience over the past two decades both from corrosion testing and also the assessment of failures which has given understanding with respect to alloy selection and corrosion rates at various temperatures. Many laboratory investigations focusing on specific aspects of corrosion in controlled atmospheres have also been undertaken to give improved understanding of corrosion mechanisms. However, there are still areas where further investigations are underway, with respect to both laboratory and field testing. The present focus areas of research include: a) Use of coatings in biomass power plants where the coatings perform differently in different biomass plants depending on fuel mix and temperature b) Importance of understanding the microstructure of component materials and how microstructure evolution with time and temperature can influence corrosion. This paper will recap past experience and highlight some of the results from the new research. Based on the brief review of research in the field, and the research described in detail in this paper, critical unresolved issues and a way forward for the industry is presented.
\end{abstract}

Keywords: biomass corrosion, power plant testing, laboratory testing,

\section{INTRODUCTION}

In order to reduce $\mathrm{CO}_{2}$ emissions, many countries are implementing combustion of biomass instead of coal. However, biomass contains aggressive species which cause severe corrosion of high temperature superheaters exposed to hot flue gases in boilers. This is related to the $\mathrm{SO}_{2}, \mathrm{HCl}$ and $\mathrm{KCl}$ species that are released during combustion. Thus high temperature corrosion is a major challenge for biomass based heat and power production.

There has been extensive research within this field, both basic research and applied research as summarized by references [1-4] and the presence of $\mathrm{Cl}$ species, especially $\mathrm{KCl}$ is clearly responsible for the high corrosion rates. Some of the key references from laboratory research which have furthered the understanding of the corrosion mechanism in biomass boilers are outlined. Thermodynamic modelling of phase stabilities of alloying elements in chlorine bearing gases was investigated by Bender et al. ${ }^{5}$ and correlated to actual exposures of a variety of commercial alloys ${ }^{6}$, thus concluding that corrosion attack could be predicted. Li et $\mathrm{al}^{7}$ compared the reaction of chromium with $\mathrm{KCl}$ as a deposit and a vapor, where $\mathrm{KCl}$ as a deposit resulted in much higher corrosion rates, however in both cases potassium chromate + unprotective chromia was formed. Reactions of $\mathrm{KCl}$ deposit with $\mathrm{Fe}, \mathrm{Cr}$, and $\mathrm{Ni}$ revealed that iron and chromium are readily attacked ${ }^{8}$ whereas $\mathrm{Ni}$ is not, and that the addition of $\mathrm{HCl}$ gas increased the corrosion rate. A reaction was observed for iron already at $300^{\circ} \mathrm{C}$, whilst for chromium the attack began at a higher temperature of $500^{\circ} \mathrm{C}$. However, not all chlorides result in attack of chromium as revealed by TGA/DTA 
where $\mathrm{Ba}, \mathrm{Ca}$ and $\mathrm{Mg}$ chlorides gave no reaction ${ }^{9}$. The coupled effect of $40 \% \mathrm{H}_{2} \mathrm{O}+5 \% \mathrm{O}_{2}$ in the gas phase and small amounts of $\mathrm{KCl}$ deposit on stainless alloys at $600^{\circ} \mathrm{C}$ was investigated by $[10,11]$ focusing on the mechanism of breakdown of the protective oxide by potassium to form potassium chromate. Sui et al ${ }^{12}$ used chronoamperometry together with XPS (to distinguish $\mathrm{Cr}^{3+}$ and $\mathrm{Cr}^{6+}$ in the corrosion product) thus revealing that the formation of potassium chromate on UNS N08028 steel already occurred in the first 3 minutes of reaction at $450^{\circ} \mathrm{C}$ and $535^{\circ} \mathrm{C}$. More recently, the use of $\mathrm{O}^{18}$ to label different oxygen species in the gas phase $\left(\mathrm{H}_{2} \mathrm{O}\right.$ and $\left.\mathrm{O}_{2}\right)$ indicated that when $\mathrm{KCl}$ is present, oxygen from $\mathrm{O}_{2}$ contributes primarily to the formation of chromate ${ }^{13}$. The comparison of $\mathrm{KCl}$ and $\mathrm{NaCl}$ attack on different alloys (ferritic and stainless steel) revealed that although there were some mechanistic differences the corrosion rates were similar ${ }^{14}$. Research has also focused on the presence of other gas species such as $\mathrm{SO}_{2}$ and $\mathrm{HCl}$ together with the $\mathrm{KCl}$ deposit $^{15,16}$. Li et al ${ }^{17,18}$ reported that $\mathrm{Al}$ and $\mathrm{Al} / \mathrm{Si}$ modified iron alloys improved corrosion resistance. Preoxidized alumina formers such as FeCrAl alloys (preoxidised at $700^{\circ} \mathrm{C}$ ) resulted in better corrosion resistance compared to the same alloys without pre-oxidation, however potassium chromates were still observed $^{19}$. When $\alpha$-alumina was formed by pre-oxidation at higher temperatures, i.e. $900^{\circ} \mathrm{C}$ and $1100^{\circ} \mathrm{C}$, the oxide was resistant to attack, however, thermal cycling resulted in mechanical failure ${ }^{20}$.

Field studies with probes or in built sections is also highly relevant to this field as the results can be used directly for materials selection in boilers, however this type of research is more costly, so the number of trials are limited. Comparison of K21590, S31000 and N06025 in a coastal fluidized bed biomass plant revealed the best performance from N06025, however the corrosion rates above $500^{\circ} \mathrm{C}$ were still unacceptably high ${ }^{21}$. Keiser et $\mathrm{al}^{22}$ exposed a probe in a recovery boiler for 1000 hours and showed that the best performing steel was Alloy 28 (UNS N08028). Another probe exposure in another pulp and paper recovery boiler was conducted for 2000 hours by Keiser et $\mathrm{al}^{23}$ and compared with laboratory testing. The best performing alloys in the plant were the low alloyed stainless steel S21500 and the nickel alloy N12160, whilst in the laboratory test S21500 and N06025 were the best performers. Probe testing in a wood fluidized bed boiler revealed that $\mathrm{S} 31000$ had the best performance ${ }^{24}$. Field testing in a test superheater loop in a waste wood fluidized bed boiler showed that the N06230 had the best corrosion resistance followed by $\$ 34709$ at $600^{\circ} \mathrm{C}^{25}$. It is clear that there is no single steel or alloy, which has the best performance in all the different environments due to variations in fuel composition and operation conditions. Field studies have also been conducted in Denmark and will be described later in the paper.

Instead of having a wrought alloy tube, which has to have sufficient corrosion resistance and creep strength, the use of coatings in a chlorine bearing environment on high strength steel tubes has been investigated. HVOF coatings have been shown to give improved protection in the laboratory ${ }^{26,27}$, however Bai et $\mathrm{a}^{28}$ noted from laboratory exposures that HVOF coatings were penetrable by oxygen, and therefore also $\mathrm{Cl}$, especially at edges. Coatings using the HVAF technique, resulting in less porous coatings than HVOF have also shown promising results in the laboratory, but it is clear that when $\mathrm{Cr}$ is present in the coating, this results in $\mathrm{Cl}$ attack. Better results were observed for a Ni-5\%Al coating ${ }^{29}$. Aluminium diffusion coatings on $9-12 \% \mathrm{Cr}$ steels revealed corrosion attack similar to the uncoated material ${ }^{30}$, however another study of aluminium diffusion coatings showed promising results ${ }^{31}$. FeCrAl coatings using the PVD technique investigated 40 different combinations of $\mathrm{Fe}-\mathrm{Cr}-\mathrm{Al}$, and the most promising coating contained 8-11 at.\% aluminium $^{32}$. However coatings have not yet shown similar promising results on actual superheaters, although $\mathrm{Cr}$ rich $\mathrm{NiCrMo}$, NiCrAl, and Fe27Cr HVOF coatings showed good corrosion resistance after 2 years exposure in the economizer area (with surface metal temperatures $<300^{\circ} \mathrm{C}$ ) of an actual biomass fired boiler $^{33,34}$.

In Denmark, firing with biomass was initially implemented in small decentralized grate-fired combined heat and power (CHP) plants combusting straw and/or woodchips, and was followed by the implementation of biomass in large-scale CHP plants. This has also included rebuilding existing coal fired units or construction of new large flexible heat and power plants for either standalone biomass firing or co- 
firing of biomass with fossil fuels. It is now the aim of Denmark to be free of fossil fuels and therefore an increased amount of biomass is to be used in thermal plants ${ }^{35}$.

Since the first use of biomass for heat and power production in 1993, a number of in situ tests of boiler materials have been carried out in Danish boilers in order to gain knowledge on corrosion rates with respect to different materials and power plant operation conditions such as temperature and fuel mix. Three types of corrosion investigations have been undertaken: (i) exposure of metal rings on air/water cooled probes (ii) exposure of test tubes in a test superheater (iii) exposure of test tubes in existing superheaters. The corrosion rates of various materials were assessed in both biomass and biomass co-firing plants with respect to temperature. This information has been used for construction of plants in the past 15 years in Denmark. The following sections will summarize what has been learnt with respect to materials selection and operation parameters. In addition some of the results of recent research projects will be discussed. The specifications of the alloys described in this paper are given in Table 1.

\section{RESULTS FROM BOILER TESTING}

\section{Fuel}

Much research has been conducted in Denmark revealing that co-firing with fossil fuels such as coal can result in acceptable corrosion rates (Figure 1) comparable to coal-firing and also reduce $\mathrm{CO}_{2}$ emissions ${ }^{36}$. This has been shown to function well in two power plants in Denmark, Studstrup with coal + straw-firing and Avedøre 2 with wood + oil-firing, and more recently wood + coal-flyash as an additive. Co-firing has also been implemented successfully in many other plants in Europe ${ }^{37}$.

However the trend in Denmark is to phase out fossil fuels and to have standalone biomass boilers, where there will be an increased use of woodchip/wood pellets compared to cereal crops such as straw ${ }^{37}$. A comparison of corrosion rates in different straw and wood fired boilers for K21590, S21500 and S34709 revealed much higher corrosion rates of straw compared to wood ${ }^{38}$. However experiences in Denmark with woodchip reveal variable corrosion rates (Figure 2) where the corrosion rate can be similar to straw-firing in some cases $^{36}$.

The molar $\mathrm{S}: \mathrm{Cl}$ ratio of the fuel is often used to describe corrosiveness of biomass fuel types where $<2$ will result in high corrosion rates, and $>4$ will result in lower corrosion problems ${ }^{39}$. Straw has a ratio of 0.5-1.5 but wood has 3-8. This is a good rule of thumb, however to get a more accurate assessment of a fuel's corrosiveness, cations have to also be introduced, for example calcium oxides can compete with the alkali chlorides for reaction with $\mathrm{SO}_{3}$ resulting in sulphation ${ }^{40}$. Also the use of aluminosilicates can neutralize $\mathrm{KCl}$ and reduce corrosion ${ }^{41}$. When firing straw, the amount of $\mathrm{KCl}$ in the ash is high, and in addition the amount of ash from the combustion process is much greater than for wood, thus resulting in high corrosion rates. The effect of different types of alumina and sulfur rich additives were assessed and compared for straw grate-firing and woodchip grate-firing plants and the conclusion was that the use of additives is viable with wood, however due to the much higher $\mathrm{Cl}$ flux for straw, additive dosing would not be feasible ${ }^{42}$.

\section{Materials Selection}

\section{Results from boiler exposures}

When firing with fossil fuels, increase of chromium content results in reduced corrosion rates since a chromium rich oxide can give better protection and stable chromium sulphides can form. In waste to 
energy plants where there are heavy metal molten chlorides, nickel alloys give improved corrosion resistance against waterwall and superheater corrosion because of the chromium and nickel content. This section describes the alloy assessment with respect to biomass corrosion. Corrosion testing was undertaken with a water and air-cooled corrosion probe inserted above the combustion zone of a strawfiring boiler ${ }^{43}$. The probe consisted of ring specimens of 8 different materials sandwiched by two rings onto which three thermocouples were welded on the inner side to measure inner metal temperature. The exposure time was 1392 hours where the probe temperature fluctuated around $450-600{ }^{\circ} \mathrm{C}$ during exposure. The average temperature difference along the probe was $12{ }^{\circ} \mathrm{C}$ and this was considered insignificant compared to the fluctuation in temperature which was time dependent and was probably due to the building up and shedding of deposit. Thus corrosion rates with respect to a specific temperature could not be given; however a ranking of materials with the fluctuating temperature and operation conditions was obtained. The specimens were measured for material loss based on initial pre-exposure measurements, and also internal attack. The results from this test revealed that total corrosion attack $(\boldsymbol{\Delta})$ could be divided into two components, material loss $(\square)$ and internal attack $(+)$ as shown in Figure 3 . The alloys with high iron content revealed very little internal attack, whilst alloys with higher chromium content were internally attacked at grain boundaries and/or within the grains resulting in a porous structure. For low alloyed steels, it is not so evident that an element is being preferentially attacked compared to the higher alloyed steels where there is internal attack and depletion of elements with a higher affinity for chlorine such as chromium.

The arrow in Figure 3 marks the data point for N08028 $(27 \% \mathrm{Cr}, 21 \% \mathrm{Ni}, 3.5 \% \mathrm{Mo}, 1 \% \mathrm{Cu}$, rest Fe) where the elemental distribution is revealed in Figure 4 undertaken using elemental mapping with scanning electron microscopy at $20 \mathrm{keV}$. In Figure 4, deep internal attack is shown in the electron micrograph which correlates to chromium depletion in the adjacent elemental map, however both iron and nickel are still present.

Other investigations using corrosion probes ${ }^{44}$ and a test superheater loop ${ }^{45}$ revealed similar trends to Figure 4, i.e. that there were high corrosion rates and deep internal attack for the alloys with higher chromium content. Possible reasons for the increased internal attack have been the basis of further investigations described later in this paper. From these studies it was clear that the optimal chromium content was between 15 - $20 \mathrm{wt} . \%$. In Denmark, many biomass plants use the $18 \% \mathrm{Cr}$ steel S34709 and maintain the steam outlet temperature to below $540^{\circ} \mathrm{C}$ to give acceptable corrosion rates. The corrosion rate for the N08028 steel shown in Figure 4 is $0.6 \mathrm{~mm} / 1000 \mathrm{~h}$, whereas much lower corrosion rates of 0,030 $-0,12 \mathrm{~mm} / 1000 \mathrm{~h}$ were measured from a $600^{\circ} \mathrm{C}$ probe exposure in a wood-fired CFB boiler ${ }^{38}$, however similar to the trend observed for straw firing, the corrosion rates for S21500 and S34709 were generally lower. It is interesting to reflect on how much of the corrosion rates was due to the high $\mathrm{Cl}$ content in the flyash from straw compared with wood, but also to what extent the combustion parameters such as flue gas composition, flue gas temperature and grate firing vs. CFB also have an influence.

\section{Future material possibilities}

Laboratory experiments have revealed that $\mathrm{KCl}$ reacts with $\mathrm{Cr}_{2} \mathrm{O}_{3}$ to form potassium chromate indicating that chromia formers cannot form a protective oxide when alkali chlorides are present ${ }^{46,47,48}$. In addition the selective $\mathrm{Cr}$ depletion from high $\mathrm{Cr}$ alloys is also observed as depicted in Figure $4^{49}$. Thus the usual approach to increase the chromium content to reduce corrosion rates is not applicable for biomass corrosion. Systematic laboratory testing of various alloys at $600{ }^{\circ} \mathrm{C}$ with a $\mathrm{KCl}$ deposit in $15 \% \mathrm{H}_{2} \mathrm{O}+3 \% \mathrm{O}_{2}+$ $\mathrm{N}_{2}$ also indicated that improved corrosion rates cannot be achieved from higher alloyed metallic materials on the market ${ }^{49}$. The reaction of $\mathrm{KCl}$ with different oxides was investigated and $\mathrm{Al}_{2} \mathrm{O}_{3}$ was not observed to react with $\mathrm{KCl}^{47}$. Thus coatings basing their protective behavior on aluminium have been developed utilizing pack cementation to aluminize both steels and nickel based alloys ${ }^{50}$. After the promising results of $\mathrm{Ni}$ aluminides obtained on a laboratory scale ${ }^{51,52}$, the demonstration of the performance of these coatings 
under real service conditions in a biomass fired plant was undertaken for two years. After 1 year's exposure, the coatings had failed in a straw firing plant with $540{ }^{\circ} \mathrm{C}$ steam temperature ${ }^{53}$ and the causes of failure were probably due to heavy thermal cycling resulting in spallation as well as local chemical breakdown of the protective scale. The failure root causes are currently being investigated in further detail $^{54}$.

\section{Temperature Assessment}

To improve the electrical efficiency of the power plant, there is a need to have higher steam data. However there is a hurdle with respect to materials selection forcing the plant to adhere strictly to an outlet steam temperature of maximum $540{ }^{\circ} \mathrm{C}$. Figure 5 shows corrosion rates from various straw-fired power plants with respect to steam temperature ${ }^{55}$. It is important to note that steam temperature is used here, as surface metal temperature is difficult to measure and will depend on various factors, for example, heat flux, flue gas direction and temperature, deposit composition and porosity, position of tube within the superheater bundle etc. In grate firing, the surface metal temperatures are approximately $20^{\circ} \mathrm{C}$ higher than the steam temperature, however slight variations in corrosion rates are observed probably due to slightly different surface metal temperatures. Although the outlet steam temperature to the turbine is measured as $<540{ }^{\circ} \mathrm{C}$, there can be a higher heat flux around some of the banks and leading tubes, resulting in higher outlet steam temperatures on single tubes due to the unevenness of flow and heat flux. Thus superheater tubes can suffer failure due to higher temperature profiles on leading tubes, or in specific banks depending on the flow dynamics within the combustion zone and boiler ${ }^{21,55}$. Therefore it is important to measure the temperature of single tubes which are assessed to be exposed to higher heat fluxes.

There is a greater range of corrosion rates at one power plant $(\square)$, which could be due to varying heat flux resulting in higher or lower surface temperature. Heat flux and flue gas temperature are difficult to measure in the plant and a higher heat flux on one side of a tube in a position close to the combustion zone can give increased surface temperature compared to the opposite side, although the measured steam temperature at the outlet will not reveal this. This leads to more corrosion on one side compared to the other. Thus a tube, generally a leading tube where the outlet temperature is measured to be within the allowable temperature can have a higher surface temperature on one side resulting in significant differences in wall thickness, and therefore unexpected failure in this area. This has in some cases led to the use of protective sleeves, which are replaced regularly as they degrade from corrosion, to reduce the high heat flux on the tubes.

\section{RESULTS FROM LABORATORY STUDIES}

\section{Flue gas parameters}

There are difficulties in mechanistic studies of corrosion reactions in the power plant because of the fluctuations in exposure conditions, and real components can be a challenge to examine by more advanced material characterization tools. Therefore in order to investigate the influence of process parameters such as flue gas and deposit composition, laboratory exposures are needed.

A series of investigations were conducted in a gaseous environment $\left(6 \% \mathrm{O}_{2}, 12 \% \mathrm{CO}_{2}, 82 \% \mathrm{~N}_{2}, 400\right.$

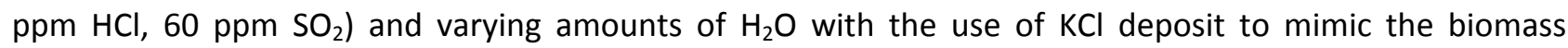
corrosion ${ }^{56,57,58}$. A deposit of $\mathrm{KCl}$ was applied as a slurry according to $\mathrm{EU}$ guidelines, which after drying was characterized as a compact layer. The results revealed that sulfation of the deposit due to $\mathrm{SO}_{2}$ occurs at the 
deposit-flue gas interface and the deposit-oxide interface, but that $\mathrm{KCl}$ salt was present in the middle ${ }^{56}$. The presence of a melt containing $\mathrm{K}-\mathrm{Cl}-\mathrm{Fe}-\mathrm{Mn}-\mathrm{Cr}$ was detected on the surface of the corrosion product indicating volatilization of metal chlorides from the corrosion front. Another interesting observation was that increased water vapor content decreased the amount of attack measured ${ }^{57}$. In addition, when $\mathrm{HCl}$ gas was not in the gas mixture, a thick potassium sulfate layer was present, and underneath there was deep pitting reminiscent of reducing conditions observed in coal gasifiers ${ }^{58}$. Earlier results in the same equipment but where the deposit was applied as a powder did not reveal deep sulfidation pitting. Instead $>80 \%$ of the deposit was sulfated after only 3 days ${ }^{16}$, thus the way the $\mathrm{KCl}$ is applied to the sample surface can affect sulfation, however it is difficult to know which method more correctly simulates the conditions in the power plant.

In addition a range of commercial alloys were tested in a more simplistic laboratory exposure with $5 \% \mathrm{O}_{2}+15 \% \mathrm{H}_{2} \mathrm{O}+\mathrm{N}_{2}+\mathrm{KCl}$ for $168 \mathrm{hrs}$ at $600{ }^{\circ} \mathrm{C}$ to enable ranking of the alloys ${ }^{48}$. The results revealed that N08028 sustained very little corrosion and was better than a $18 \% \mathrm{Cr}$ steel. Other studies ${ }^{46}$ revealed a similar trend for $\mathrm{N} 08028$ and $\mathrm{S} 30403$ steels exposed in a $\mathrm{O}_{2}+40 \% \mathrm{H}_{2} \mathrm{O}+\mathrm{KCl}$ environment. These results are in contradiction to results from the plant exposures mentioned earlier ${ }^{43,45}$ (cf. Figure 3 and 4 ) indicating that it is difficult to simulate the actual plant conditions in the laboratory.

However, another example of the effect of variable exposure conditions is shown in Figure 6 where N08028 revealed different corrosion attack morphologies when exposed in slightly changed setups ${ }^{48}$. This could indicate that the presence of water vapor as previously shown results in lower attack, and in laboratory air where the specimen is suspended over a $\mathrm{KCl}$ deposit, deep grain boundary attack was observed although the general attack was modest. Again it is difficult to be sure which method would give a more correct ranking of the steels in the plant, but it is important to relate rankings to what occurs in the plant, and try to change the laboratory exposure method accordingly.

Older studies compared isothermal exposures with gradient temperature testing (where a higher gas temperature was used and a lower metal temperature) and revealed an increased corrosion rate in the presence of a temperature gradient (Figure 7$)^{59}$ but only when ash deposits were present. The flue gas mixture used was $7.3 \% \mathrm{H}_{2} \mathrm{O}, 19 \% \mathrm{CO}_{2}, 8 \% \mathrm{O}_{2}+300 \mathrm{ppm} \mathrm{SO} \mathrm{S}_{2}$ and $200 \mathrm{ppm} \mathrm{HCl}$ and when ash was present this could react with the deposit and also result in either melt phases or release of corrosive species within the ash which could attack the underlying alloy. Where there was no ash deposit, the reaction rates were governed by the surface metal temperature only. Again the N08028 steel was more protective than the $18 \% \mathrm{Cr}$ steel in both air and simulated flue gas, but the corrosion rates for the gradient temperature testing are actually comparable to those measured in Figure 3. The exposure times were maximum 168-310 hours, and a real ash from a power plant was used. More recent work looking at ash deposition on gradient probes has shown that a higher flue gas temperature promotes the ingress of $\mathrm{Cl}$ species to the corrosion front ${ }^{60}$ and this was also shown in deposit analysis in a gradient temperature furnace ${ }^{61}$. Thus a thermal gradient could result in a higher metal temperature, promoting the volatilization of metal chlorides from the corrosion front and also lead to ingress of $\mathrm{Cl}$ species to the corrosion front.

\section{Assessment of preferential attack}

Thermodynamic calculations of the steel and alloy types investigated in Figure 3 revealed that the materials which incurred high internal attack coincide with those where the precipitation of $\mathrm{Cr}$-rich phases such as $\alpha-\mathrm{Cr}$ and $\sigma$-phase are predicted. Based on these observations the mechanisms for internal corrosion and the chromium depletion which ultimately leads to the higher material loss are being investigated in detail with emphasis on the influence of precipitation reactions. During exposure, a steel tube will undergo microstructural changes as a result of thermal ageing and it is important to know to what extent these 
changes can influence or lead to preferential attack. This could be a reason for differences in the laboratory data where the exposures are short term and compared to longer term plant studies.

To investigate this, a modified S31000 steel (see Table 1 ) was chosen which forms 29 vol. \% $\sigma$-phase after heat treatment at $700{ }^{\circ} \mathrm{C}$ for 10,000 hours. Experiments were conducted in $5 \% \mathrm{O}_{2}+15 \% \mathrm{H}_{2} \mathrm{O}+\mathrm{N}_{2}+\mathrm{KCl}$ deposit for $168 \mathrm{hrs}$ at $600{ }^{\circ} \mathrm{C}^{62}$. Furthermore it had been confirmed by long term isothermal heat treatments that $\sigma$-phase will not form at the test temperature $\left(600{ }^{\circ} \mathrm{C}\right)$ for the duration of the test $(168 \mathrm{~h})$. Figure 8 reveals the deep corrosion attack for the heat treated steel compared to the as received (solution treated) steel with light optical microscopy (LOM). Thus the corrosion rates measured for an as received steel may be different from the aged steel, although the composition is the same. The susceptibility for similar steels to internal attack may be dependent on microalloying of the steel which influences formation of precipitates during ageing. Currently laboratory exposures and analysis are being undertaken to compare corrosion response of aged $\mathrm{S} 34709$ tubes from a power plant compared to as received material to reveal whether there are differences that can be related to ageing.

Investigation of exposed tubes of S21500 from boilers where different fuels were combusted revealed the presence of dark $\mathrm{Cr}$ rich precipitates immediately below the corrosion front on the fireside in the BSE mode of scanning electron microscopy ${ }^{63}$. Similar dark $\mathrm{Cr}$ rich precipitates have also been identified for the S34709 FG steel below the corrosion front (Figure 9). The actual compositions of these $\mathrm{Cr}$ rich precipitates have not been identified, but their darker color in the back-scattered image could indicate that they are carbides. The presence of such precipitates on exposed tubes could be due to ageing, but also could be due to reactions at the corrosion front with carbides or carbon dioxide from the flue gas. Further analysis is being undertaken with respect to the presence and composition of precipitates and whether they can influence the selective attack observed for austenitic steels.

\section{CRITICAL UNRESOLVED ISSUES}

The initial mechanism of chlorine corrosion and what is the rate determining step is still not clear and different theories have been suggested including electrochemical reactions or diffusion of $\mathrm{Cl}$ atoms, ions or molecules ${ }^{64,65}$. Measuring surface reactions at high temperatures is very demanding and tailored experiments for example with labelled molecules ${ }^{13}$ together with mathematical models ${ }^{65}$ would give a better insight into the process.

Corrosion in biomass plants is difficult to simulate using laboratory exposures due to the vastly different parameters in different biomass plants with different fuel types. Based on gas analyses (usually undertaken as a single measurement during a campaign) or deposit analyses (obtained when the plant is shutdown), simplistic laboratory testing has been undertaken to understand some of the reactions occurring. However, sometimes results utilizing slightly different set-ups are in contradiction with each other and also corrosion rates observed in the power plant. For materials and coatings development, fast laboratory corrosion testing is desirable, however it is also important that the laboratory corrosion testing mimics trends and reveals a similar type of attack to that observed in the boiler. The optimal way to obtain the parameters needed for laboratory testing would be on-line in situ analysis of the corrosion environment during combustion. Trials with in situ measurements in a burner rig have shown for example, that the concentration of chlorine in deposits decreases with a temperature rise to about $700{ }^{\circ} \mathrm{C}$ and after a reduction of the metal temperature, the chlorine concentration increases again ${ }^{66}$. Use of in situ measurements have not previously been undertaken and applied to laboratory testing and this could give invaluable chemical information to be used in laboratory testing. It has been suggested that $\mathrm{KOH}$ could contribute to the corrosion attack, but this compound reacts with flue gas components during cooling and 
therefore has never been identified in deposits collected from plants ${ }^{67}$, however obtaining data from in-situ measurements would clarify such questions.

When the optimal parameters for laboratory corrosion have been identified, parameter studies can also be undertaken. Areas which are in need of research include the flue gas reactions with $\mathrm{KCl}$ deposit resulting in release of corrosive species and what factors could affect this, e.g. flue gas composition including varying steam concentrations, or presence of oxides. In addition due to the local variation in biomass availability and economic aspects, there is a growing tendency to use lower qualities and cheaper types of biomass such as waste wood, manure, bark, bone meal, rice husks, and the effect of using these fuels together with possible additives on corrosion is not always clear. If the plant owner has limited tools to predict corrosion with lower biomass qualities, the plant will be run at a lower temperature and therefore lower efficiency to avoid potential problems. Realistic testing in the laboratory would eliminate this worry.

The effect of ash deposition and how this relates to corrosion rates has not been sufficiently understood. If a fuel has high ash content, this will result in a thick ash deposit containing corrosive $\mathrm{KCl}$ resulting in corrosion; however, it will also protect against the higher flue gas temperature and in this way insulate the tube. The localized flue gas temperature also affects migration of $\mathrm{KCl}$ to the corrosion front as has been simulated in a gradient furnace ${ }^{61}$. If a fuel with less ash content is used, which is perhaps not so corrosive, then a very thin ash layer will condense on the tubes, perhaps resulting in a higher localized temperature. Thus the amount of ash and also the characterization of the ash, whether it is porous or molten/semi molten may relate to both ingress of $\mathrm{KCl}$ and localized surface metal temperatures resulting in different corrosion rates.

The collection of plant data for UNS34709 has revealed that there are increased corrosion rates above a steam temperature of $540^{\circ} \mathrm{C}$ in grate-fired boilers using straw as shown in Figure 5 . Although it is clear that corrosion will increase with temperature, the temperature where there are unacceptable corrosion rates may be slightly higher or lower for different alloys and may also depend on the type of boiler (grate-firing, fluidized bed, suspension-fired). A similar comparison of data for candidate alloys is needed in different boiler types.

It is clear that with $\mathrm{KCl}$ in the biomass, chromia formers will not give similar corrosion resistance compared to coal-firing. The use of alumina formers has been identified as a possibility where adequate protection can be given by $\alpha$-alumina (which forms at $>900^{\circ} \mathrm{C}$ ) ${ }^{20}$, however pre-oxidizing at such a high temperature may compromise the tubes strength which could be fatal for a high pressure component. Therefore it is important that a protective alumina layer is formed at lower temperatures, which can be rapidly healed when cracking occurs during exposure, and is also resistant to chemical attack from $\mathrm{KCl}$ after long exposures. The use of other minor alloying elements, whose oxides do not react with $\mathrm{KCl}$ could be another possible route for a protective coating.

\section{SUMMARY}

* The materials limitations and temperature limitations when firing biomass (straw) have been documented from field experiences and laboratory investigations. For the available materials, the $15-18 \% \mathrm{Cr}$ steels result in best performance. The steam temperature of $540{ }^{\circ} \mathrm{C}$ is the maximum viable temperature in biomass firing, as above this there are exceptionally high corrosion rates. The preliminary work indicates that the microstructure that develops during exposure can have a negative effect on corrosion rate, however further studies are required in this area. 
* A better knowledge of the heat flux and temperature dynamics in the plant are needed to assess the surface metal temperature as the corrosion increases rapidly at about $540{ }^{\circ} \mathrm{C}$ leading to unforeseen failures.

* Laboratory testing in a flue gas simulating biomass firing has resulted in a better understanding of attack, and the roles of different gas constituents. The varying results observed in different laboratory set-ups can help us identify which reactions are important and are the rate determining reactions for corrosion in the boiler. They can also help us to understand the different corrosion rates that are observed in different boilers, for example boilers with different water content in their flue gas or grate-firing, suspension firing or fluidized bed boilers.

\section{ACKNOWLEDGEMENTS}

This work is conducted within the ForskEL project 12289 which is a collaboration between DTU-Mekanik and $\emptyset$ rsted, and financed by energinet.dk. The work is also supported by the KME 714 project. 


\section{REFERENCES}

1. W.B.A Sharp, D.L. Singbeil, J.R. Keiser: Superheater Corrosion Produced by Biomass Fuels" Proceedings Corrosion 2012 Paper C2012-0001308 (Houston, TX: NACE 2012)

2. W.B.A Sharp, D.L. Singbeil, J.R. Keiser: "Energy from Biomass - Lessons from European Boilers", TAPPI PEERS conference 2011 vol 2, p 583-689.

3. J.R. Keiser, W.B.A. Sharp, D.L. Singbeil, "Could biomass-fuelled boilers be operated at higher steam temperatures? 2. Field Tests of Candidate Superheater Alloys" Tappi Journal 138 (2014) p. 51-63.

4. D. Mudgal, S. Singh, S. Prakash "Corrosion Problems in Incinerators and Biomass-Fuel-Fired Boilers" International Journal of Corrosion, (2014) Article IS 505306.

5. R. Bender, M. Schütze "The role of alloying elements in commercial alloys for corrosion resistance in oxidising-chloridising atmospheres Part I Literature evaluation and thermodynamic calculations on phase stabilities" Materials and Corrosion 54 (2003): p. 567-586.

6. R. Bender, M. Schütze, "The role of alloying elements in commercial alloys for corrosion resistance in oxidizing-chloridizing atmospheres Part II: Experimental investigations" Materials and Corrosion 549 (2003): p. 652-686.

7. Y.S. Li, M. Sanchez-Pasten, M. Spiegel, "High Temperature Interaction of Pure $\mathrm{Cr}$ with $\mathrm{KCl}$ " Materials Science Forum, 461-464 (2004): p. 1047-1054.

8. S.C. Cha, M. Spiegel, "Studies on the local reactions of alkali chloride particles on metal surfaces" Materials and Corrosion 57 (2006) p. 159-164.

9. J. Lehmusto et al., "High temperature oxidation of metallic chromium exposed to eight different metal chlorides" Corrosion Science 53 (2011): p. 3315-3323.

10. J. Pettersson et al " $\mathrm{KCl}$ induced corrosion of a 304-type austenitic stainless steel at 600C: The role of potassium" Oxidation of Metals 64, (2005) p. 23-41.

11. T. Jonsson et al., "The Influence of $\mathrm{KCl}$ on the Corrosion of an Austenitic Stainless Steel (304L) in Oxidizing Humid Conditions at 600C: A Microstructural Study" Oxidation of Metals 72 (2009): p. 213239.

12. J. Sui et al., "The onset of potassium chloride induced high temperature corrosion: A novel experimental approach" Oxidation of Metals 82 (2014): p.437-457.

13. J. Lehmusto et al., "The Effect of Oxygen Source on the Reaction Mechanism of Potassium chlorideinduced High-Temperature Corrosion" CORROSION 7412 (2018): p.1431-1445.

14. S. Enestam et al., "Are $\mathrm{NaCl}$ and $\mathrm{KCl}$ equally corrosive on superheater materials on steam boilers" Fuel 104, (2013): p. 294-306.

15. S. Karlsson et al., "KCl-induced high temperature corrosion of the austenitic stainless steel $304 \mathrm{~L}$ - The influence of $\mathrm{SO}_{2}$ " Materials Science Forum 696 (2011): p. 224-229.

16. S. van Lith, M. Montgomery, F.J. Frandsen, "Lab-scale investigation of deposit-induced chlorine corrosion of superheater materials under simulated biomass-firing conditions" Energy and Fuels 23, (2009): p. 3457-3468.

17. Y.S. Li, M. Spiegel, "Internal Oxidation of Fe-Al alloys in a $\mathrm{KCl}$-Air atmosphere at $650 \mathrm{C}$ " Oxidation of Metals 61 (2004): p. 303-322.

18. Y.S. Li, Y. Niu, M. Spiegel: "High temperature interaction of $\mathrm{Al} / \mathrm{Si}$ modified $\mathrm{Fe}-\mathrm{Cr}$ alloys with $\mathrm{KCl}$ " Corrosion Science 49 (2007): p. 1799-1815

19. N. Israelsson et al, " $\mathrm{KCl}$ induced corrosion of an FeCrAl alloy at $600 \mathrm{C}$ in $\mathrm{O} 2$ and $\mathrm{H} 2 \mathrm{O}$ environment: The effect of preoxidation" Oxidation of Metals 83 (2015): p. 29-53.

20. N. Israelsson et al, "Cyclic corrosion and chlorination of an FeCrAl alloy in the presence of KCl" Oxidation of Metals 84, (2015): p.269-290.

21. J. R. Kish et al, "Corrosion of High-Alloy Superheater Tubes in a Coastal Biomass Power Boiler", CORROSION 644 (2008): p.356-366. 
22. J.R. Keiser, J.R. Kish, D.L. Singbeil: "Recovery Boiler Superheater Corrosion Field Study", Proceedings Corrosion 2010, Paper No 10081 (Houston, TX: NACE 2010)

23. J.R. Keiser et al , "Performance of Alternate Superheater Materials in a Potassium-Rich Recovery Boiler Environment", Tappi Journal 127 (2013): p.45-56.

24. P.J. Henderson, T. Eriksson, J. Tollins, T. Åbyhammar, "Corrosion testing of superheater steels for $600 \mathrm{C}$ steam in biomass/co-fired boilers" Advanced Heat Resistant Steel for Power Generation, Editor. R. Viswanathan and J. Nutting (1998)

25. P. Henderson, M. Lundberg, "Corrosion of superheaters at $600 \mathrm{C}$ in biomass-fired boilers" 9th Liege Conference: Materials for Advanced Power Engineering, Editors J. Lecomte-Beckers, Q. Contrepois, T. Beck and B. Kuhn (2010): p.1116-1125.

26. A. Bellucci et al, "Effect of Al Enrichment by Pack Cementation of FeCr Coatings Deposited by HVOF" Journal of Thermal Spray Technology 24 (2015): p. 244-251.

27. S. Paul, M.D.F. Harvey, "Corrosion testing of Ni Alloy HVOF coatings in high temperature environments for biomass applications" Journal of Thermal Spray Technology 22 (2013): p. 316-327.

28. M. Bai, L. Reddy, T. Hussain, "Experimental and thermodynamic investigations on the chlorine-induced corrosion of HVOF thermal sprayed NiAl coatings and 304 stainless steels at 700C" Corrosion Science 135 (2018): p. 147-157.

29. E. Sadeghimeresht et al, "Chlorine-induced high temperature coatings of HVAF-sprayed Ni-based alumina and chromia forming coatings" Corrosion Science 132 (2018): p. 170-184.

30. J. Metsäjoki, E. Huttunen-Saarivirta, T. Lepistö "Elevated-temperature corrosion of coated and aluminized 9-12\% Cr boiler steels beneath KCl deposit" Fuel 133 (2014): p. 173-181.

31. V. Vokál et al., "Corrosion of alloys and their diffusion aluminide coatings by $\mathrm{KCl}: \mathrm{K} 2 \mathrm{SO} 4$ deposits at $650^{\circ} \mathrm{C}$ in air" Materials and Corrosion 59 (2008): p. 374-379.

32. D. Orlicka Ph.D thesis, "Development of novel coatings to resist fireside corrosion in biomass-fired power plants" July 2016, Cranfield University, U.K.

33. M. Oksa et al., "Nickel-based HVOF coatings promoting high temperature corrosion resistance of biomass-fired power plant boilers" Fuel Processing Technology 125 (2014): p. 236-245.

34. M. Oksa, T. Varis, K. Ruusuvuori, "Performance testing of iron based thermally sprayed HVOF coatings in a biomass-fired fluidised bed boiler" Surface \& Coatings Technology 251 (2014): p.191-200.

35. "Environmental report for Danish electricity and CHP for 2016 status year" Environmental Report 2017 from energinet.dk, https://en.energinet.dk/-/media/Energinet/El-RGD/Miljrapport-2017 EN.pdf accessed January 2018.

36. O.H. Larsen, M. Montgomery, "Materials problems and solutions in biomass fired plants" Energy and Materials 1, (2006): p. 227-237.

37. W.R. Livingston, The status of large scale biomass firing, Edited by J. Koppejan and M.F.G. Cremers Published by IEA Bioenergy 2016

38. P. Henderson et al., "In Situ Fireside Corrosion Testing of Superheater Materials with Coal, Wood and Straw Fuel for Conventional and Advanced Steam Temperatures" VGB PowerTech 6, (2005): p. 53-59.

39. K. Salmenoja, K. Makela, "Prevention of superheater corrosion in the combustion of biofuels" CORROSION 2000, Paper 00238 (Houston, TX: NACE 2000).

40. M. Aho et al., "Effective new chemicals to prevent corrosion due to chlorine in power plant superheaters" Fuel 87, (2008): p. 647-654.

41. T. Hardy, W. Kordylewski, K. Moscicki, "Use of aluminosilicate sorbents to control $\mathrm{KCl}$ vapors in biomass combustion gases". Journal of Power Technologies 93, 1 (2013): p. 37-43.

42. O.H. Larsen et al., "Relations between combustion, deposition, flue gas temperatures and corrosion in straw-fired boilers" Proc. 2nd World Conference and Technology Exhibition on Biomass for Energy and Industry, paper OD7.2 Rome 10-14th May 2004.

43. M. Montgomery, A. Karlsson, "In-situ corrosion investigation at Masned $\varnothing$ CHP plant - a straw-fired power plant" Materials and Corrosion 50, (1999): p. 579-584. 
44. N. Henriksen, O.H. Larsen, "Corrosion in ultrasupercritical boilers for straw combustion" Materials at High Temperatures 14, 3 (1997): p. 227-236.

45. M. Montgomery, A. Karlsson, O.H. Larsen "Field test corrosion experiments in Denmark with biomass fuels Part 1: Straw-firing" Materials and Corrosion 50, (2002): p. 579-584.

46. C. Pettersson et al., "KCl-induced high temperature corrosion of the austenitic Fe-Cr-Ni alloys 304L and Sanicro 28 at $600^{\circ} \mathrm{C}^{\prime \prime}$ Corrosion Science 48, 6 (2005): p. 1368-1378.

47. S. Kiamehr et al., "High Temperature Corrosion due to Biomass Firing: A Study on the Reactivity between Potassium Chloride and Oxides", International Symposium on High-Temperature Oxidation and Corrosion 2014, Hakodate, Hokkaido Japan 23-27 June 2014.

48. S. Kiamehr et al., "KCl-induced high temperature corrosion of selected commercial alloys Part I: chromia-formers" Materials and Corrosion 66, 12 (2015): p.1414-1429

49. S. Kiamehr Ph.D thesis, "Materials Solutions to Mitigate the Alkali Chloride-Induced High Temperature Corrosion" November 2014, DTU Mechanical Engineering, Denmark.

50. S. Kiamehr et al., "Application of aluminium diffusion coatings to mitigate the $\mathrm{KCl}$-induced high temperature corrosion" Materials and Corrosion 68, (2017): p. 82-94

51. D. Wu et al., "Laboratory Investigations of Ni-Al Coatings Exposed to Conditions Simulating Biomass Firing", Proceedings of the $9^{\text {th }}$ International Symposium of High Temperature Corrosion and Protection of Materials, 15-20 May 2016 Les Embiez, France.

52. K.V. Dahl et al., "Characterization of pack cemented Ni2Al3 coating exposed to $\mathrm{KCl}(\mathrm{s})$ induced corrosion at $600{ }^{\circ} \mathrm{C}^{\prime \prime}$ Materials at High Temperatures 35, 1-3 (2018): p. 267-274.

53. D.L. Wu et al., "Microstructural investigations of $\mathrm{Ni}$ and $\mathrm{Ni}_{2} \mathrm{Al}_{3}$ coatings exposed in biomass power plants" Materials at High Temperatures 35, 1-3 (2018): p. 255-266.

54. D.L. Wu et al., "Effects of Different Fuel Specifications and Operation Conditions on the Performance of Coated and Uncoated Superheater Tubes in Two Different Biomass-Fired Boilers" Applied Energy Materials, 1, 4 (2018) p. 1463-1475.

55. M. Montgomery et al., "Experiences with high temperature corrosion at straw-firing power plants in Denmark" Materials and Corrosion 62, (2011): p. 593-605.

56. S.C. Okoro et al., "Effect of flue gas composition on deposit induced high temperature corrosion under laboratory conditions mimicking biomass firing. Part I Exposures in oxidizing and chlorinating atmospheres" Materials and Corrosion 68: (2017): p. 499-514.

57. S.C. Okoro et al., "Effect of water vapour on high temperature corrosion under laboratory conditions mimicking biomass firing" Energy and Fuels 29, (2015): p.5802-5815.

58. S.C. Okoro et al., "Effect of flue gas composition on deposit induced high temperature corrosion under laboratory conditions mimicking biomass firing. Part II Exposures in $\mathrm{SO} 2$ containing atmospheres" Materials and Corrosion 68, (2017): p. 515-528.

59. M. Montgomery, E. Maahn "Laboratory study of high temperature corrosion in straw fired power plants" Proceedings Eurocorr 1997, Trondheim.

60. Y. Laxminarayan et al., "Tensile Adhesion Strength of Biomass Ash Deposits - Effect of Temperature Gradient and Ash Chemistry" Energy \& Fuels, published online 2018

61. D. Lindberg et al., "Effect of temperature gradient on composition and morphology of synthetic chlorine-containing biomass boiler deposits", Fuel Processing Technology 141, (2016): p 285-298.

62. Y.C. Malede et al., "Effect of microstructure on $\mathrm{KCl}$ corrosion attack of modified AISI 310 steel" Materials at High Temperatures 35, 1-3 (2018): p. 243-254.

63. M. Montgomery et al., "High Temperature Fireside Corrosion of Esshete 1250 in Coal, Co-firing with Biomass and Biomass Power Plants" Proceedings Eurocorr 2017, 3-7 ${ }^{\text {th }}$ September 2017 Prague, Czech Republic.

64. N. Folkeson, L.G Johansson, J.E. Svensson, "Initial stages of the HCl-induced High Temperature Corrosion of Alloy 310" J. Electrochemical Society 1549 (2007): C515-C521. 
65. B. Rammer, M.C. Galetz, "Kinetics of volatilization of high temperature corrosion products and its application to chlorine corrosion" Materials and Corrosion 682 (2017): p. 186-196

66. K. Davidsson, D. Ryde, "Online analys av heta påsalg vid förbränning" Energiforskrapport 2015:186 (in Swedish).

67. T. Blomberg 2011, "A thermodynamic study of the gaseous potassium chemistry in the convection sections of biomass fired boilers" Materials and Corrosion 627 (2011): p.635-640. 
Table 1: Specifications of alloys described in this paper in wt.\%

\begin{tabular}{|c|c|c|c|c|c|c|c|c|c|}
\hline & $\mathrm{C}$ & $\mathrm{Si}$ & $\mathrm{Mn}$ & $\mathrm{Cr}$ & $\mathrm{Mo}$ & $\mathrm{Ni}$ & $\mathrm{N}$ & $\mathrm{Cu}$ & Other \\
\hline N08028 & $\leq 0.020$ & $<0.70$ & $<2.0$ & $26.0-28.0$ & $3.0-4.0$ & $30.0-32.0$ & $<0.11$ & $0.70-1.50$ & \\
\hline S34709 & $0.04-0.10$ & $<1.00$ & $<2.00$ & $17.9-20.0$ & & $9.0-13.0$ & & & $\mathrm{Nb} / \mathrm{TaxC}>1.00$ \\
\hline S32100 & $<0.08$ & $<1.0$ & $<2.0$ & $17.0-19.0$ & & $9.0-12.0$ & & & $\mathrm{Ti}: 5 \times(\mathrm{C}+\mathrm{N})<0.80$ \\
\hline $\begin{array}{l}\text { Modified } \\
\text { S31000* }\end{array}$ & 0.088 & 0.023 & 0.84 & 23.8 & & 22 & 0.03 & 2.77 & $\begin{array}{c}\mathrm{Ti} 0.27 ; \mathrm{Nb} 0.36 ; \\
\mathrm{W} 2.46 ; \mathrm{V} 0.36\end{array}$ \\
\hline
\end{tabular}

*Actual measured composition 
FIGURE 1: Comparison of corrosion rate for S34709 FG (fine-grained) austenitic steel with variable fuel mix $^{36}$. FIGURE 2: S34709 FG (fine grained) exposed at a woodchip boiler revealing varying corrosion rates and corrosion morphology ${ }^{36}$.

FIGURE 3: Corrosion rates for different materials exposed on a cooled probe ${ }^{43}$

FIGURE 4: SEM micrographs of N08028 showing chromium, iron and nickel elemental distribution ${ }^{43}$.

FIGURE 5: Corrosion rates of S34709 for some straw-fired power plants in Denmark ${ }^{55}$.

FIGURE 6: Comparison of two types of corrosion attack for N08028 48 a) $5 \% \mathrm{O}_{2}+15 \% \mathrm{H}_{2} \mathrm{O}+\mathrm{N}_{2}+\mathrm{KCl}$ for $168 \mathrm{hrs}$ at 600 ${ }^{\circ} \mathrm{C}$ for $\mathrm{N} 08028$ steel, b) $\mathrm{KCl}$ in static air at $600{ }^{\circ} \mathrm{C}$ where steel specimen $\mathrm{N} 08028$ is not directly in contact with $\mathrm{KCl}$

FIGURE 7: Comparison of corrosion rates for samples exposed to varying gas compositions and temperatures (gas/metal). Flue gas $=7.3 \% \mathrm{H}_{2} \mathrm{O}, 19 \% \mathrm{CO}_{2}, 8 \% \mathrm{O}_{2}+300 \mathrm{ppm} \mathrm{SO}_{2}$ and $200 \mathrm{ppm} \mathrm{HCl}$.

FIGURE 8: Light optical micrographs of a modified $\mathrm{S} 31000$ steel after exposure in a $15 \%(\mathrm{v} / \mathrm{v}) \mathrm{H}_{2} \mathrm{O}(\mathrm{g})+5 \%(\mathrm{v} / \mathrm{v})$ $\mathrm{O}_{2}(\mathrm{~g})+\mathrm{N}_{2}(\mathrm{~g})$ atmosphere at $600{ }^{\circ} \mathrm{C}$ for $168 \mathrm{~h}$ covered with $\mathrm{KCl}$ a) as received modified $\mathrm{S} 31000$ b) heat-treated modified S31000.

FIGURE 9: Morphology of fireside oxide on S34709 FG in clean wood pellets + oil/coal-flyash after 101100 hours a) Fireside oxide b) below corrosion front c) etched to reveal precipitates. White arrows mark the corrosion front. 


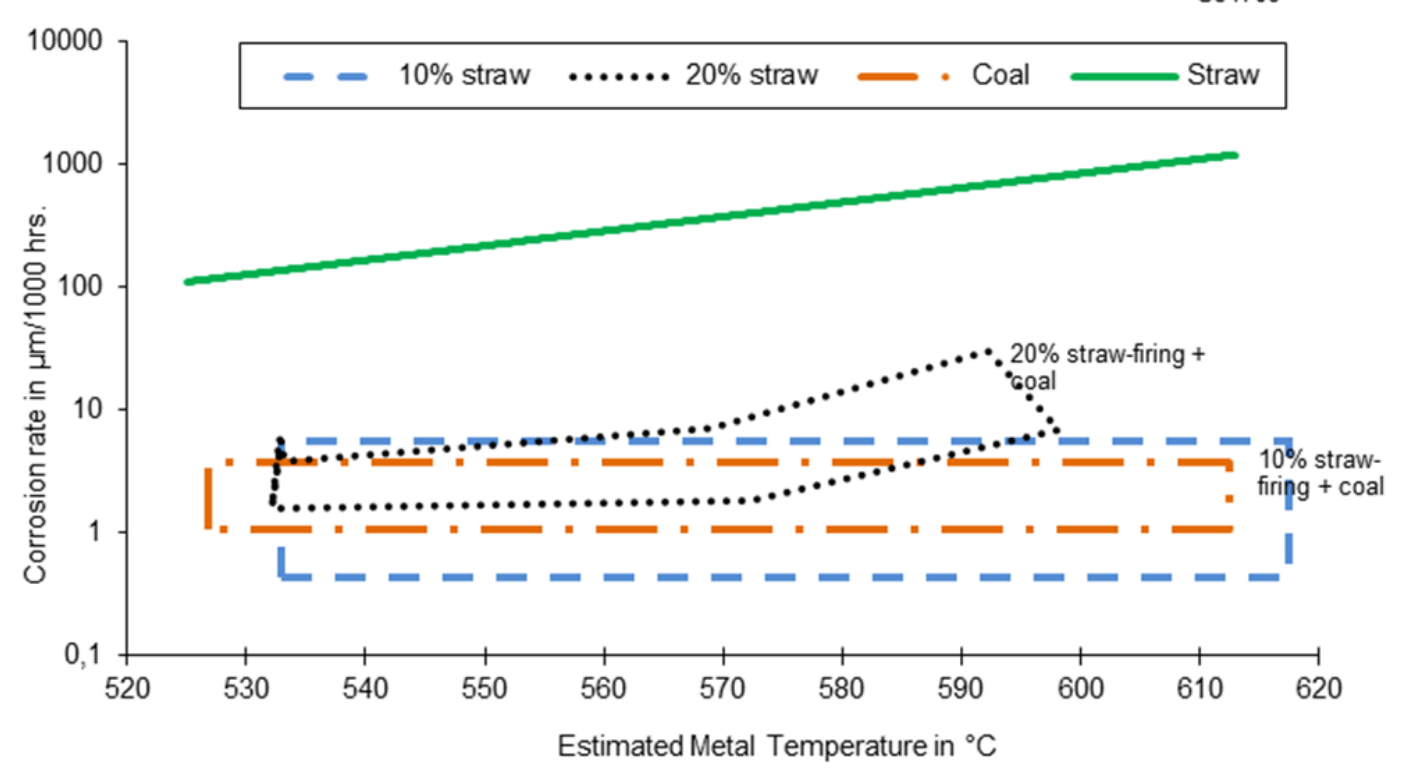

FIGURE 1: Comparison of corrosion rate for \$34709 FG (fine-grained) austenitic steel with variable fuel mix $^{36}$.

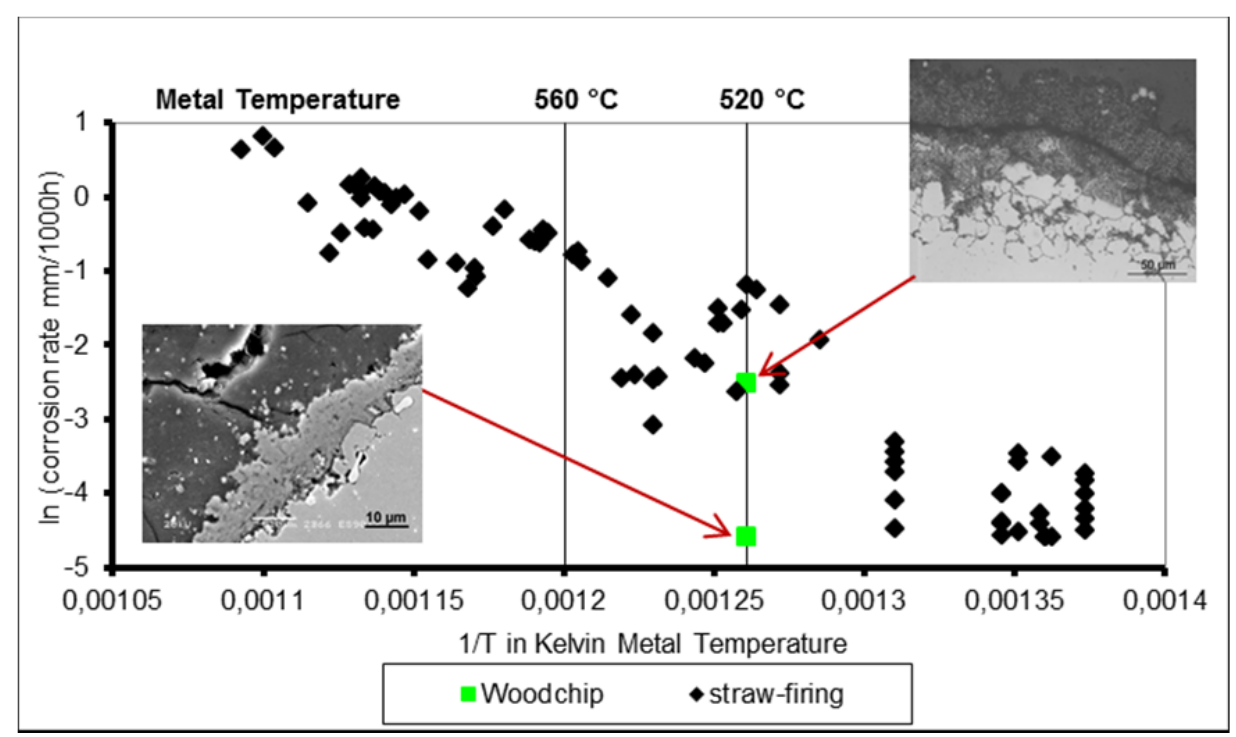

FIGURE 2: S34709 FG (fine grained) exposed at a woodchip boiler revealing varying corrosion rates and corrosion morphology ${ }^{36}$. 


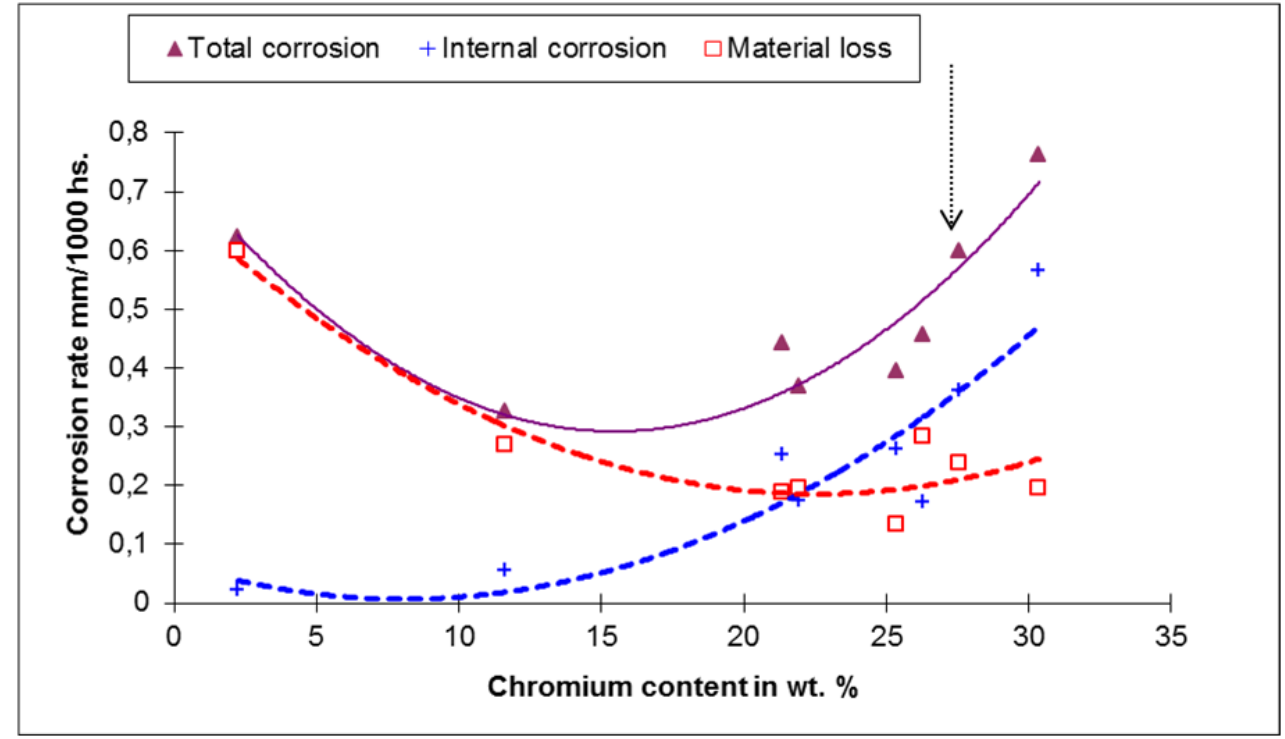

FIGURE 3: Corrosion rates for different materials exposed on a cooled probe ${ }^{43}$
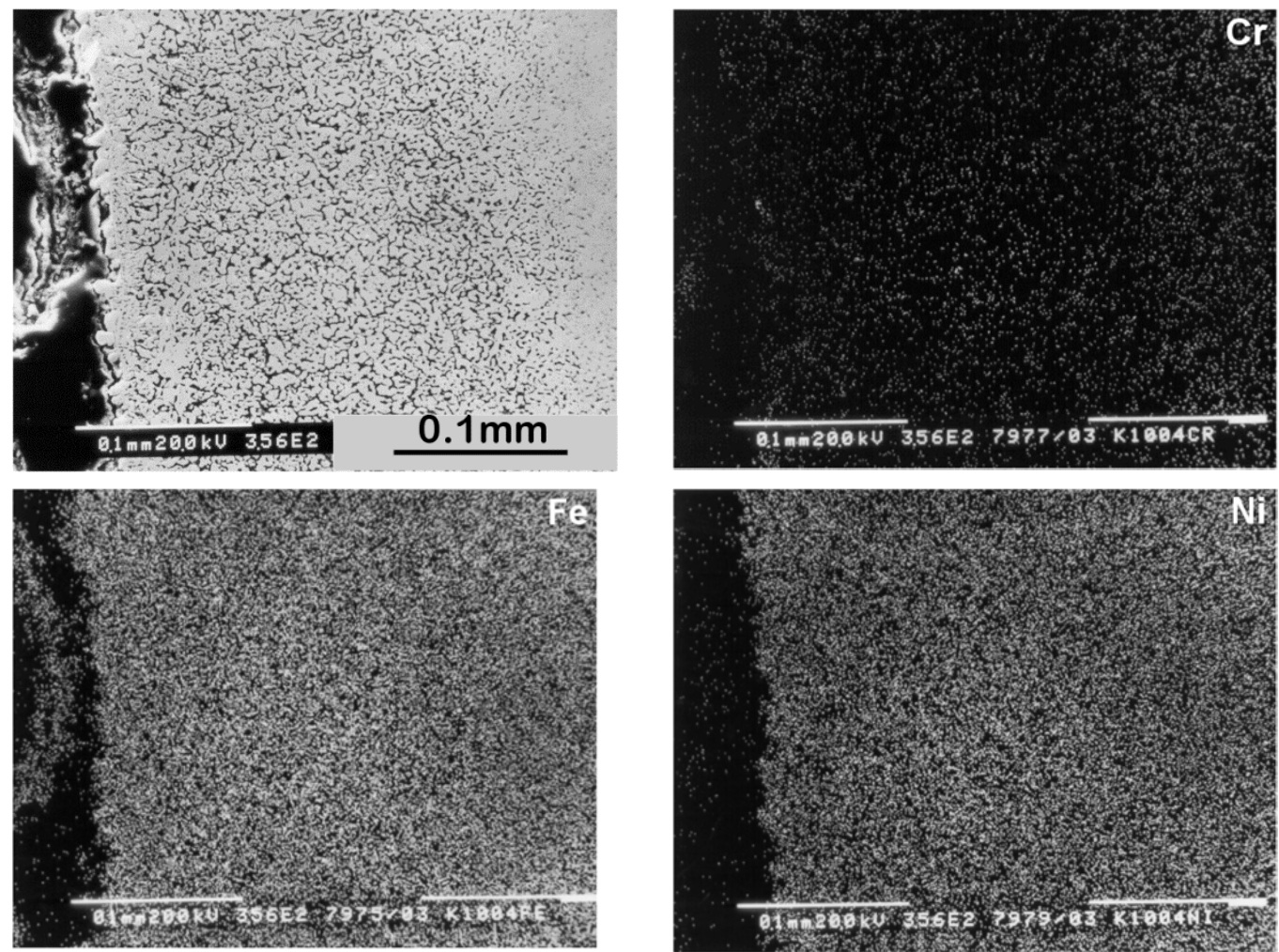

FIGURE 4: SEM micrographs of N08028 showing chromium, iron and nickel elemental distribution ${ }^{43}$. 


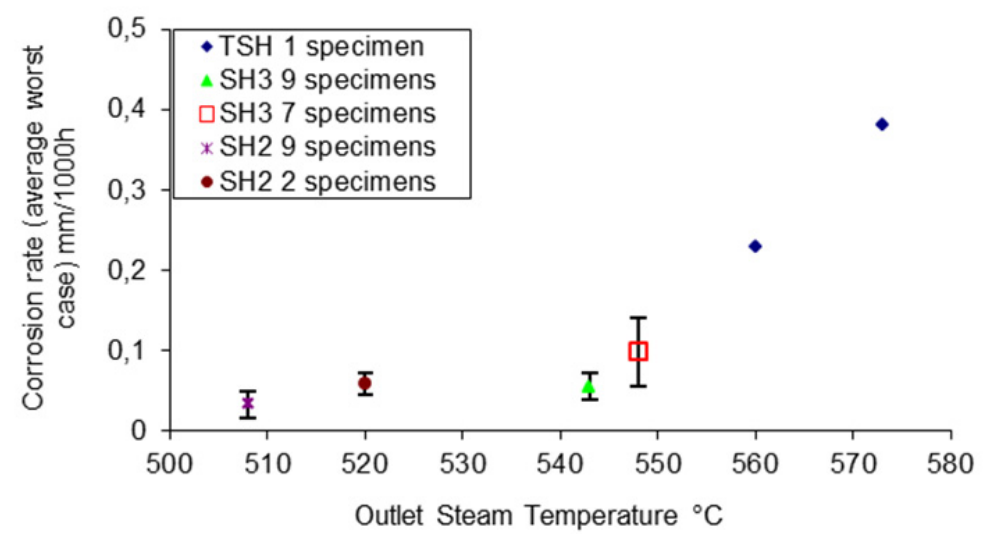

FIGURE 5: Corrosion rates of $\mathbf{S 3 4 7 0 9}$ for some straw-fired power plants in Denmark ${ }^{55}$.

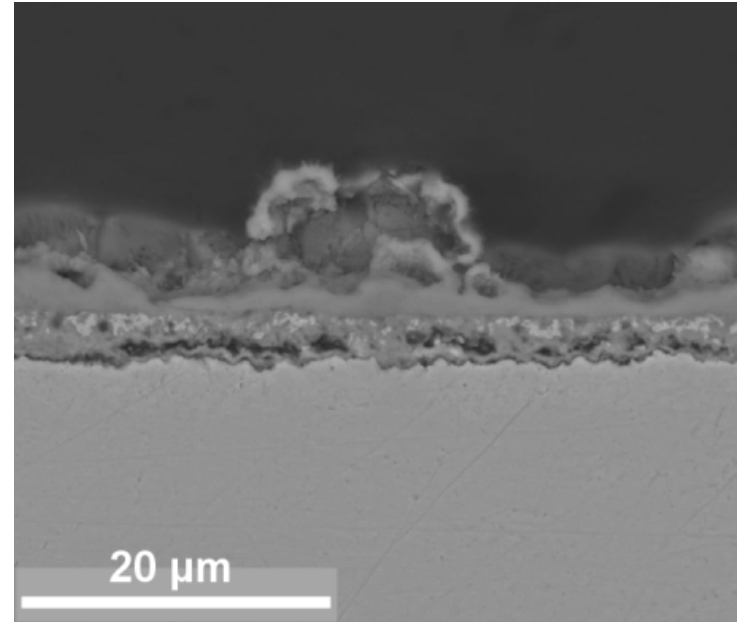

a)

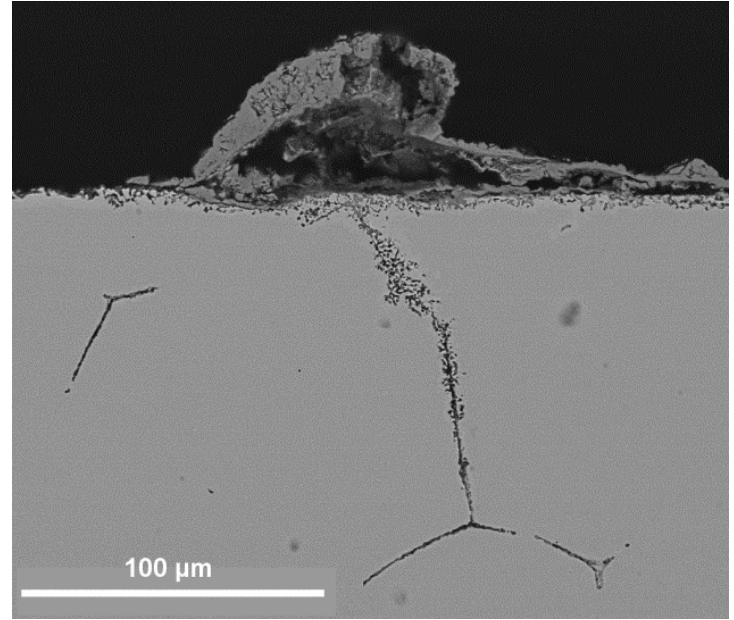

b)

FIGURE 6: Comparison of two types of corrosion attack for $\mathrm{N}^{2} 8028^{48}$ : a) $5 \% \mathrm{O}_{2}+15 \% \mathrm{H}_{2} \mathrm{O}+\mathrm{N}_{2}+\mathrm{KCl}$ for $168 \mathrm{hrs}$ at $600{ }^{\circ} \mathrm{C}$ for $\mathrm{N08028}$ steel, b) $\mathrm{KCl}$ in static air at $600{ }^{\circ} \mathrm{C}$ where steel specimen N08028 is not directly in contact with $\mathrm{KCl}$ 


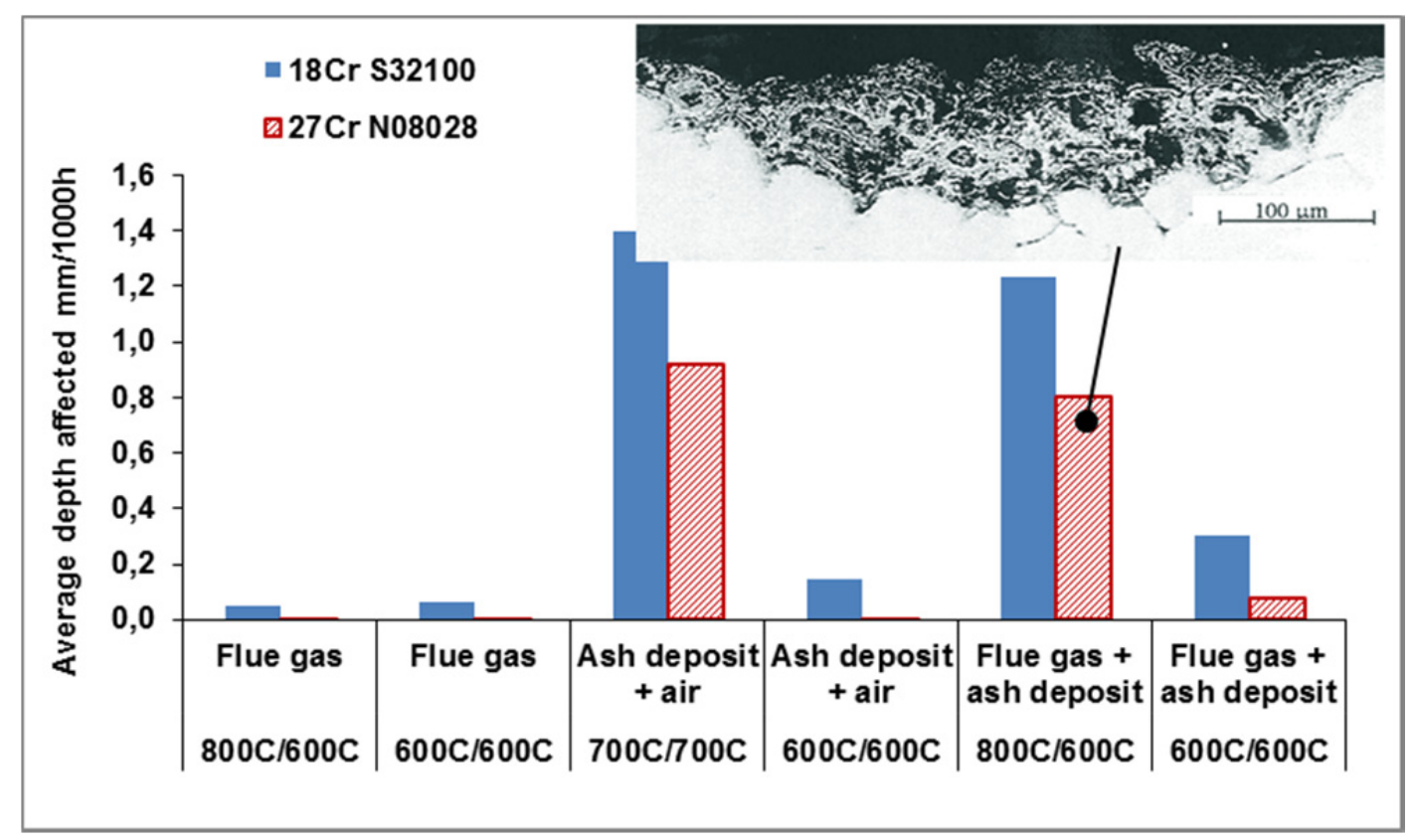

FIGURE 7: Comparison of corrosion rates for samples exposed to varying gas compositions and temperatures (gas/metal). Flue gas $=7.3 \% \mathrm{H}_{2} \mathrm{O}, 19 \% \mathrm{CO}_{2}, 8 \% \mathrm{O}_{2}+300 \mathrm{ppm} \mathrm{SO} \mathrm{S}_{2}$ and $200 \mathrm{ppm} \mathrm{HCl}$.

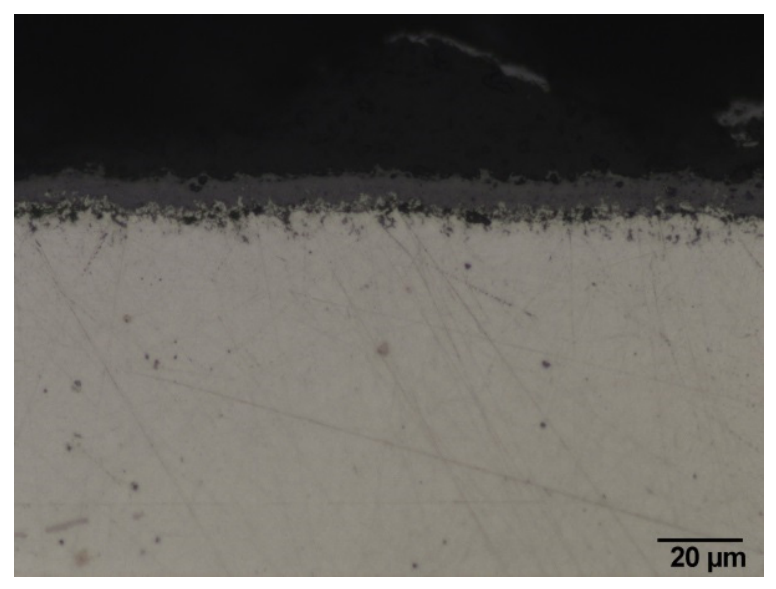

a) as received modified S31000

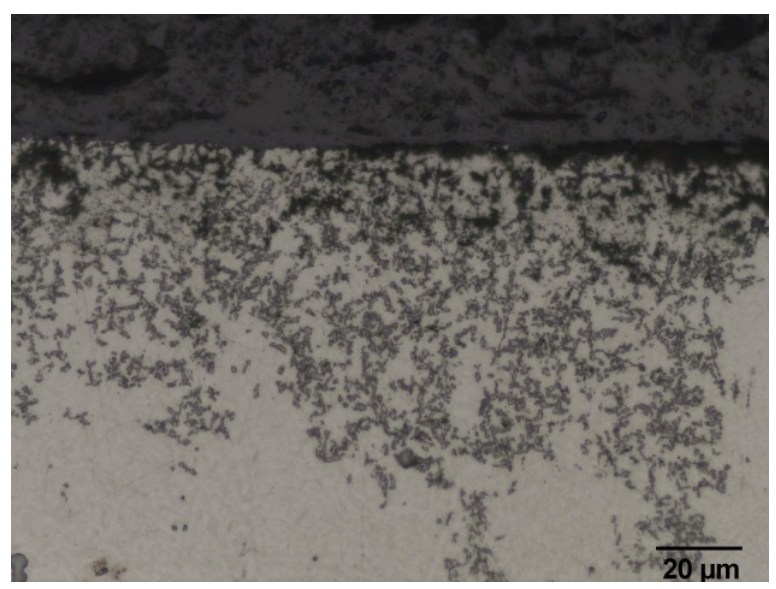

b) heat-treated modified S31000

FIGURE 8: Light optical micrographs of a modified $\mathrm{S} 31000$ steel after exposure in a $15 \%(\mathrm{v} / \mathrm{v}) \mathrm{H}_{2} \mathrm{O}(\mathrm{g})+$ $5 \%(\mathrm{v} / \mathrm{v}) \mathrm{O}_{2}(\mathrm{~g})+\mathrm{N}_{2}(\mathrm{~g})$ atmosphere at $600^{\circ} \mathrm{C}$ for $168 \mathrm{~h}$ covered with $\mathrm{KCl}$ a) as received modified $\mathrm{S31000}$ b) heat-treated modified S31000. 


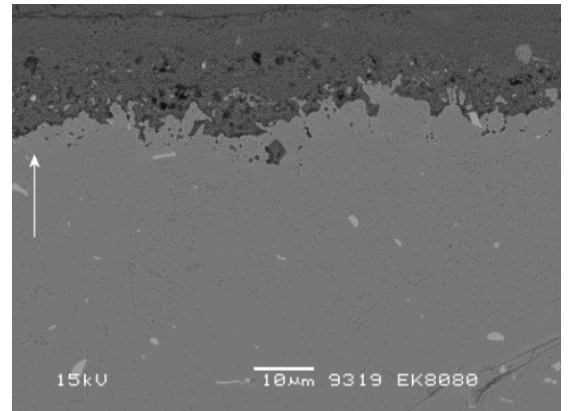

a) fireside oxide

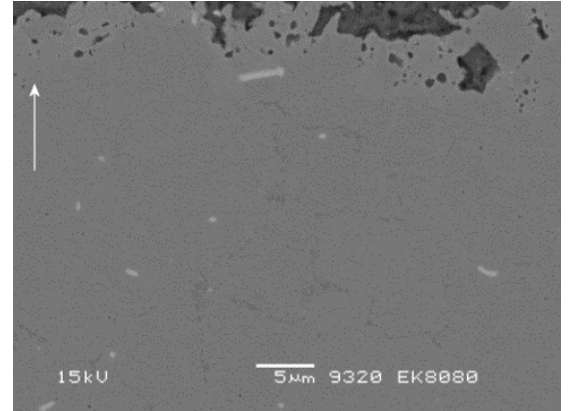

b) below corrosion front

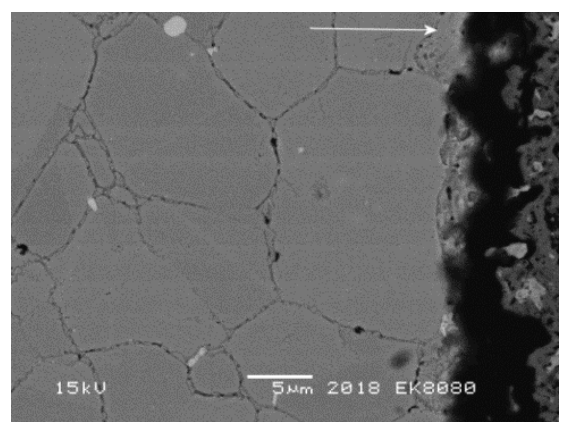

c) etched to reveal precipitates

FIGURE 9: Morphology of fireside oxide on S34709 FG in clean wood pellets + oil/coal-flyash after 101100 hours a) Fireside oxide b) below corrosion front c) etched to reveal precipitates. White arrows mark the corrosion front. 